\title{
Multipurpose Agricultural Robot
}

\author{
Ms. Aditi D. Kokate', Prof. Priyanka D.Yadav² \\ Student E\&TC Department, Dr. Daulatrao Aher College of Engineering, Karad, India \\ Assistant Prof. E\&TC Department, Dr. Daulatrao Aher College of Engineering, Karad, India,
}

\begin{abstract}
This paper is to develop a robot capable of performing operations like automatic seeding, irrigation, fertilization. It also provides manual as well as auto control. The main component here is the ARDUINO that supervises the entire process. At the present time, robots are increasingly being integrated into working tasks to replace humans especially to perform repetitive task. Seeding is one of the first steps in farming. During this process seeding is carried out in all the rows of the farming plot. In irrigation process, the soil sensor used for monitoring the environmental condition. It checks this level and alerts the farmer, then slowly applies small amount of water to the planted seeds in all the rows of the farming plot. The fertilization process is same as irrigation process but some crops need fertilizers when the seed germinates and the plant begins to grow. The robot works on solar energy.
\end{abstract}

Keywords: Solar panel, ARDUINO, Seeding, Irrigation, Fertilization, Soil sensor.

\section{INTRODUCTION}

The main aim of agricultural robotics is apply robotics technologies on the field of agriculture as well as the agricultural challenges to develop new techniques. Now days, no one can end up the day without using any kind of embedded system products. It makes our human life very robust and makes work comfortable. The 21 st century is said to be century of creation, progress, globalization and so much else, but the second side too, that is nothing but 21 st century is century of the population, global warming, drought and cloud burst also helpless health factors! Automation in agricultural robotics system has been developed to implement a number of agricultural productions in many countries. Such as picking, harvesting monitoring, weeding, seeding, fertilizer, irrigation. But in this project functions included are soil based applications of Seeding, Fertilizer, and Irrigation. The purpose of this project is to design, minimize the labour of farmers in addition to increasing the speed of the work as well as increase the yield of agriculture.

A robot which performs manual and automatic operation, this is useful for the humans. In this project, it is shown that the farm cultivation process in autonomous agriculture system which is controlled by ARDUINO. The technique of seed operation in sowing is based on row per column depending on the types of cultivation. The irrigation process slowly applies water to the sown seeds in all the rows and columns of the farming plot. In fertilization process, fertilizer is sprayed on all the plants.

\section{PROPOSED SYSTEM}

In this system Agribot is a robot designed for agricultural purpose. Here our purpose is to build a system whose data is acquired through the use of $\mathrm{X}, \mathrm{Y}, \mathrm{Z}$ plotter (Open Source System). The robot can be autonomous or controlled manually and can perform variety of tasks with great accuracy. In this project there are two switches, auto and manual.

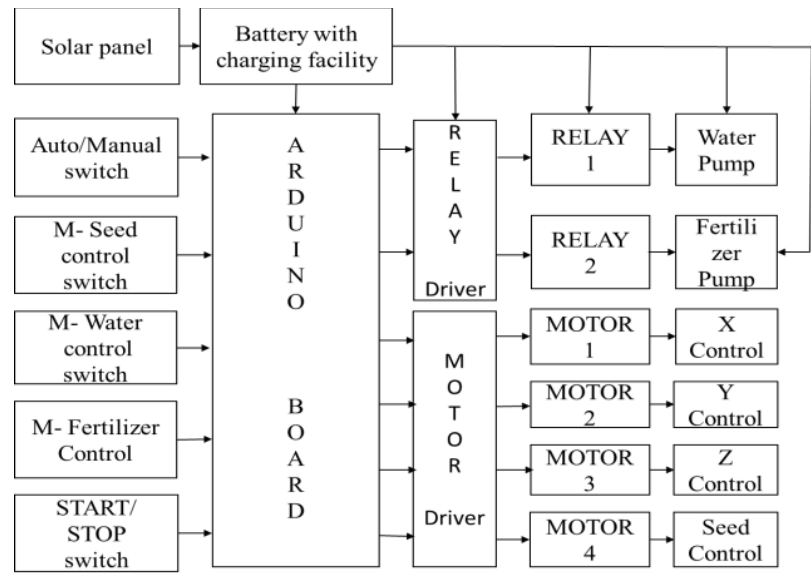

Fig. 1. Block diagram of proposed system

A. Auto / Manual Switch

This switch is used to operate our farm boat in either Automatic Mode or Manual Mode.

\section{B. M- Seed Control}

This switch is used for manual Seed Control. If you press this switch then only seeding operation is done automatically.

\section{M-Water Control}

This switch is used for manual water feed Control. If you press this switch then only watering operation is done automatically.

\section{M-Fertilizer Control}

This switch is used for manual fertilizer feed Control. If you press this switch then only fertilizer operation is done automatically. 
IARJSET

International Advanced Research Journal in Science, Engineering and Technology

National Conference on Emerging trends in Electronics \& Telecommunication Engineering (NCETETE 2017)

AGTI's Dr. Daulatrao Aher College Engineering, Vidyanagar Extension, Karad

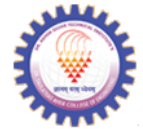

Vol. 4, Special Issue 2, January 2017

E. Start / Stop Control

This switch is used to start or stop the project operation.

\section{F. ARDUINO Board}

ARDUINO does not need separate piece of hardware (programmer). In order to load new code on to the board you can simply used a USB cable. It is a flexible.

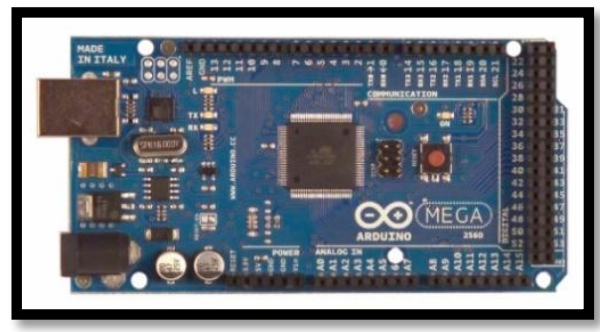

Fig. 2. Arduino board

\section{G. Relay Driver}

The operation of relays driver is to switch on or off the relay.

\section{H. Motor Driver}

Specially used to drive the DC motors. In our project motors are used to control the direction in $\mathrm{x}, \mathrm{y}, \mathrm{z}$ axis and seeding control.

\section{Relay}

This electromechanical switch is used to operate pumps. These pumps operate on $12 \mathrm{~V}$ DC.

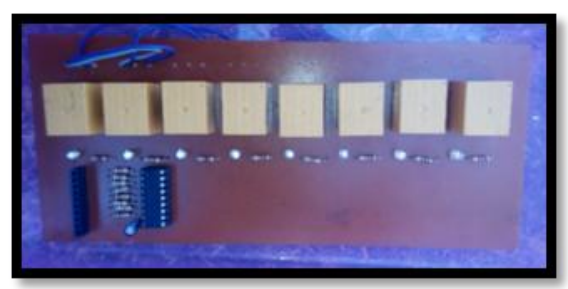

Fig. 3. Relay board

\section{WORKING}

A. Manual Operation

When manual switch is pressed, manual operation is performed as follows, when M-seed control button is pressed, then seeding is carried out in all the rows of the farming plot. When M-water control button is pressed, then the planted seeds in all the rows of the farming plot are watered. When M-fertilizer control button is pressed, then fertilizer is sprayed on all the plants. Some crops want fertilizers when the seed germinates and the plant begins to grow. Manual operation is best suited for such crops. The other crops can work with automatic operation.

\section{B. Automatic Operation}

The other technique used is auto mode. In this system when auto switch is pressed, M-seed control, M-water control and $\mathrm{M}$-fertilizer control operations are performed automatically. For robot motion X, Y, Z plotter is used by DC-motor. This project is developed to carry out the seeding, watering and fertilization operations for one row at a time within the farming plot. In future system are modified for more than one row at a time.

For seeding operation there are different techniques:

\section{- Hydraulic System}

In this system vacuum is used to pick the seed and compressor is used for the digging purpose. By using hydraulic system seeding operation is performed effortlessly and accurately. But the cost of the vacuum and compressor are very high. So this is not purchasable for rural people.

\section{- $\quad$ Funnel Technique}

In this technique seeds are gathered in the funnel, then top of the funnel is covered by wood material. We create some slope on wood so that the seed will move out from the funnel. This hole connects to the seeding pipe. To rotate the motor we use dc motor. In this project funnel technique is used for seeding.

\section{FLOWCHART}

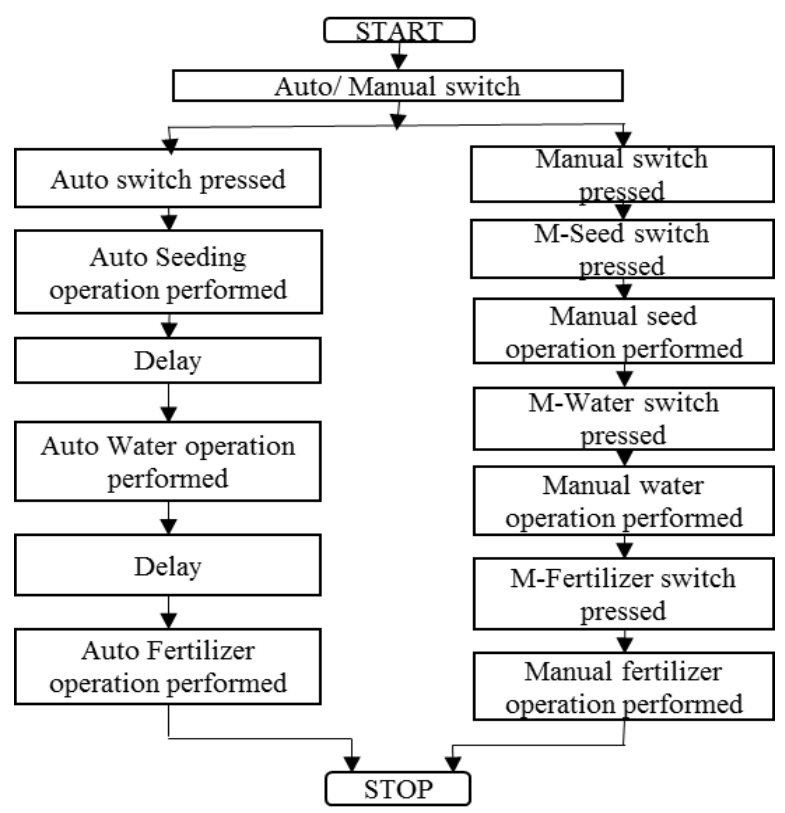

Fig. 4. Flow chart

\section{EXPECTED RESULT}

The robot operates on automated mode as well as manual mode. The main purpose of manual mode is, if you require anyone function then press particular manual switch. Suppose M-water switch is press then watering operation is performed. In auto mode, when auto switch is pressed then all operation like seeding, Irrigation, Fertilization are perform automatically. All manual and auto mode operations are performed on open source system. For power consumption purpose use renewable (Solar) energy. 
IARJSET

International Advanced Research Journal in Science, Engineering and Technology

National Conference on Emerging trends in Electronics \& Telecommunication Engineering (NCETETE 2017)

AGTI's Dr. Daulatrao Aher College Engineering, Vidyanagar Extension, Karad

Vol. 4, Special Issue 2, January 2017

TABLE I

\begin{tabular}{|c|c|c|}
\hline Switch & Condition & Output \\
\hline Start & $\mathrm{ON}$ & $\begin{array}{l}\text { System started } \\
\text { working condition. }\end{array}$ \\
\hline M-Seed & ON & $\begin{array}{l}\text { Seeding is carried out } \\
\text { all the rows. }\end{array}$ \\
\hline M-Water & $\mathrm{ON}$ & Seeds are watered. \\
\hline $\begin{array}{c}\text { M- } \\
\text { Fertilization }\end{array}$ & $\overline{\mathrm{ON}}$ & $\begin{array}{c}\text { Fertilizer sprayed on } \\
\text { the plant. }\end{array}$ \\
\hline Auto & ON & $\begin{array}{l}\text { Three function } \\
\text { performed is } \\
\text { automatic. }\end{array}$ \\
\hline Stop & ON & System is at halt. \\
\hline
\end{tabular}

\section{CONCLUSION}

This project is mainly based on minimizing man power as well as cost of the equipment. The robot can be with open source system instead of normal robotic car. Automation is needed such as industry, bio-medical, survey line etc. Especially in agriculture field for increasing yield of crops. Flexibility of automation system is high than traditional system. The advantage of this system reduce the labour cost, and time. In this work a robot is built and established to carry out automatic and manual seeding, Irrigation, Fertilization in an agriculture field. The functioning of the robot is performed by renewable energy like solar energy. It is expected that the robot will support the farmers in improving the efficiency of operations in their farms.

It can help the farmers in the initial stage of agriculture.

\section{TABLE II COMPARISON BETWEEN TRADITIONAL} AND MODERN METHOD

\begin{tabular}{|c|c|c|c|c|}
\hline $\begin{array}{c}\text { Sr. } \\
\text { No. }\end{array}$ & $\begin{array}{c}\text { Parame } \\
\text { Ter }\end{array}$ & $\begin{array}{c}\text { Traditio } \\
\text { nal }\end{array}$ & Tractor & $\begin{array}{c}\text { Robo } \\
\text { tic }\end{array}$ \\
\hline I & Speed & Slow & High & Very high \\
\hline II & Man power & More & Moderate & Less \\
\hline III & $\begin{array}{c}\text { Time } \\
\text { required }\end{array}$ & More & Less & Less \\
\hline IV & $\begin{array}{c}\text { Sowing } \\
\text { technique }\end{array}$ & $\begin{array}{c}\text { Manuall } \\
\text { y }\end{array}$ & Manually & $\begin{array}{c}\text { Automatic } \\
\text { ally }\end{array}$ \\
\hline V & $\begin{array}{c}\text { Required } \\
\text { energy }\end{array}$ & High & $\begin{array}{c}\text { Very } \\
\text { high }\end{array}$ & Less \\
\hline VI & $\begin{array}{c}\text { Yield of } \\
\text { crop }\end{array}$ & Low & Moderate & High \\
\hline
\end{tabular}

\section{FUTURE SCOPE}

Apart from seeding, irrigation, fertilization and fruit picking, harvesting, weeding, monitoring etc. can also be implemented in this robot. And one or more system can be, monitoring through the image processing and GSM system. Then it also includes weeding and harvesting in this system.

\section{ADVANTAGES}

- No wastage of water.

- Time consumption.

- Less manpower is required.

- Row to row spacing can be adjusted.

\section{APPLICATIONS}

\section{- $\quad$ Nursery}

The Agribot is used in nursery for row to row spacing can be adjusted, Required seed spacing can be achieved as well as variety of seed can be sowing by this robot.

\section{- $\quad$ Farm}

In farm Agribot is used for planted seeds in all the rows of the farming plot are watered and fertilizer is sprayed on all the plants. Some crops need fertilizers when the seed germinates and the plant begins to grow.

\section{Greenhouse}

In greenhouse the Irrigation and Fertilization operation performed precisely.

\section{REFERENCES}

[1] Nitin P. V., Shivprakash,"Multipurpose Agricultural Robot", International Journal Of Engineering Research Vol.5, Issue, 06, PP:1129-1254, 20 May 2016.

[2] Abhishek Gupta, Shailesh Kumawat \& Shubham Garg ,"Automatic Plant Watering System", Imperial Journal of Interdisciplinary Research (IJIR) Vol-2, Issue-4, 2016.

[3] Manjuath Pail, Sandesh Sharma, Chaitra Krishna, Chaithanya, Sandeep S., "A Study on Semi Automatic Vegetable Planting Machine"National Conference on Advances in Mechanical Engineering Science (NCAMES-2016).

[4] Akhila Gollakota, "A Multipurpose Agricultural Robot ", Birla Institute of Technology and Science, Hyderabad Campus.

[5] Andrew English, Patrick Ross , Devid Ball, "Learning Crop Models for Vision - Based Guidance of Agricultural Robot", 2015 IEEE / RSG International Conference on Intelligent Robots and System (IROS), Sept 28-Oct 02, 2015.

[6] Swetha S. and Shreeharsha G.H., "Solar Operated Automatic Seed Sowing Machine", International Journal of Advanced Agricultural Sciences and Technology 2015, Volume 4, Issue 1, pp. 67-71.

[7] Snehal M. Deshmukh, Dr.S.R.Gengaje,"ARM- Based Pesticide Spraying Robot", International Journal of Engineering Research and General Science Volume 3, Issue 3, Part-2, May-June, 2015.

[8] Rana Biswas, Romit Beed, Ankita Bhaumik, Shamik Chakrabarty \& Raghav Toshniwal,"Solar-Powered Automated Plant/Crop Watering System", International Journal of Advanced Engineering and Global Technology I Vol-03, Issue-01, January 2015.

[9] Swati D.Sambare, S.S.Belsare," Seed Sowing Using Robotics Technology", International Journal of scientific research and management (IJSRM), Volume- 3, Issue-5, 2015.

[10] Sriwongras P., Dostal P., "DEVELOPMENT OF SEEDER FOR PLUG TRAY", Department of Technology and Automobile Transport, Faculty of Agronomy, Mendel University in Brno, Zemedelska 1, 61300 Brno, Czech Republic.

[11] Amrita Sneha. A, Abirami. E. Ankita. A, Mrs. R. Praveena, Mrs. Srimeena, "Agricultural Robot for Automatic Ploughing and Seeding",2015 IEEE International Conference on Technological Innovations in ICT for Agriculture and Rural Development (TIAR 2015).

[12] Divya C. H. Ramakrishna, H. and Praveena Gowda, Seeding and Fertilization using an Automated Robot ", International Journal of Current Research Vol.5, Issue, 03, pp.461-466, March, 2013.

[13] Satish KumarKN, Sudeep CS, "Robots for Precision Agriculture", 13th National Conference on Mechanisms and Machines, IISc, Bangalore, India, December 12-13, 2007. 